\title{
Empowerment of Small Businesses through The Implementation of Qardhul Hasan Financing
}

\author{
Masyhuri Machfudz* and Nahdhiatun Kamila \\ Study Program of Agribusiness, Universitas Islam Malang \\ (Received October 10, 2019; Accepted November 28, 2019; Published December 12, 2019)
}

\begin{abstract}
The research aims to describe Qardhul Hasan financing and recognize the problems faced in micro businesses in the city of Malang. The study was conducted on two research objects. The first study was on a used motorcycle dealer business that received Qardhul Hasan during the 2016-2018 period. The second study in 2019, was the implementation of Qardhul Hasan in small-scale creative economy traders, whose source of funding came from $2.5 \%$ of profits from used motorcycle dealers. The results showed that the implementation of Qardhul Hasan financing was quite profitable. Qardhul Hasan who is allocated to the creative economy group indicates a feeling of happiness and calm because loan repayments are not burdened with costs, besides having flexibility from the time of repayment. Economic actors managed to collect savings from repaying loan installments. Qardhul Hasan funding received a reasonably good response from economic actors. Qardhul Hasan loan recipients should be able to maintain trust and uphold the agreements that have been built. This study has implications for the development of Qardhul Hasan, namely strengthening the concept of Qardhul Hasan as loan financing, and strengthening groups for small businesses to run the Qardhul Hasan management mechanism.
\end{abstract}

Keywords: qardhul hasan, sharia financing, small business, loan

JEL Classification: D14, Q21, G51

\section{INTRODUCTION}

Sharia financial institutions and services have developed rapidly in Indonesia, especially since the enactment of Law No. 7 of 1992, which was later amended in Law No. 10 of 1998. These laws provide a basis for the legality and operation of Sharia financial institutions and provide much opportunity to increase the performance of banks, financial institutions and the national economy.

The business performance of Islamic financial shows distinction compared to conventional institutions. This is mainly based on two reasons. First, the view that the interest rate in conventional banks is in the category of usury that is contrary to religion. Second, the imposition of business risk, especially to one party (the borrower) at a conventional bank is considered to violate the

* Corresponding author email: masyhuri033@gmail.com ISSN 2615-6075 online; ISSN 2615-6946 print @UWG Press, 2019

OJS http://publishing-widyagama.ac.id/ejournalv2/index.php/jsed/ principles of justice and partnership. At Sharia bank institutions, capital return applies with a profit sharing system, calculated based on profits and losses through a contract agreement charged to the creditor and debtor. The Sharia banking system has similarities with conventional banking systems in terms of looking for profits and public services in the financial business. However, both of them have differences in terms of the return system provided to customers (Cahyono \& Kurniawan, 2017).

Sharia banking system has been functioned since in 1992, which was started by the operation of Bank Muamalat Indonesia (BMI). BMI was the first sharia bank implementing a profit sharing system. During the 1998 economic crisis, Indonesia's economy experienced a collapse, resulting in high interest rates and inflation. BMI as a Sharia Bank was the only bank that is able to survive in a crisis situation, while the conventional banks' business was in bankruptcy. This shows that the banking system with usury (interest) is not resistant to economic crises and subsequently generates distrust from its customers. As a result, 
customers then look for the alternative, Islamic banking, to meet their needs.

Abduh \& Azmi Omar (2012) state that Islamic financial development is positively and significantly correlated with economic growth and capital accumulation. Domestic financing provided by the Islamic banking sector shows a significant contribution to the growth of the Indonesian economy. In other words, Islamic banking is effective as financial intermediaries that facilitate the transmission of funds from surplus households to deficit households. The relationship between Islamic financing and growth in Indonesia is bidirectional, indicating that the development of Islamic banking stimulates growth and at the same time, the growth propels the Islamic banking development in Indonesia.

In Indonesia, Islamic banking shows a progressive performance with the robust performance of banking indicators. Its operations engage non-bank financial institutions, Islamic money and capital markets and takaful (Islamic insurance) with the ultimate target in financing the real sector and improving the economy. However, there are still some challenges to be solved in particular, like the small market share, the lack of human resources and, the lack of product development (Ismal, 2011).
Now, the number of Islamic banks has grown rapidly to various regions. Conventional banks also open sharia divisions or open offices with separate management. In the Malang area, 28 Islamic Sharia banks and sub-branch offices have been built. Bank Muamalat has two operational cash offices, BRI Syariah has 5 sub-branch offices, BNI Syariah has 3 sub-branch offices, Bank Mandiri Syariah has 7 sub-branch offices. Other banks also have sharia management, including BTN Syariah, Panin Syariah Bank and Mega Syariah Bank.

Islamic banking services are very diverse. Sharia services guarantee the goodness and security againts usury practices. Various sharia financial services show diversity including mudaraba, musharaka, wadiah, bai (bai murabahah, salam or istishna), rahn, ijarah, hawalah, wakalah, kafalah and qardh (Utomo, Maharani, \& Octavio, 2016). These services received a variety of responses by the people. A positive response is shown by the Muslim population because it provided the implications of sharia-based life according to Islamic values. The response was surprising because Islamic bank transactions still resemble conventional banks, for example, the burden of administrative costs, profit sharing, and other transaction costs (Purwadi, 2014).

Table 1. The Composition of Shariah Financing in Commercial Bank in Indonesia

\begin{tabular}{lrrrrr}
\hline Indicator & \multicolumn{1}{c}{2015} & 2016 & 2017 & 2018 & 2019 \\
\hline & $\ldots \ldots \ldots \ldots \ldots \ldots \ldots \ldots$ & Billion rp & $\ldots \ldots \ldots \ldots \ldots \ldots \ldots \ldots \ldots$ \\
Profit Sharing Financing & 55886 & 62151 & 67536 & 74541 & 72983 \\
1. Mudharabah & 8431 & 8012 & 7050 & 5889 & 5708 \\
2. Musyarakah & 47455 & 54139 & 60486 & 68652 & 67275 \\
Piutang, Receivables & 97075 & 114009 & 120028 & 125044 & 124393 \\
1. Murabahah & 93647 & 110101 & 114534 & 118181 & 117693 \\
2. Qardh & 3308 & 3883 & 5476 & 6848 & 6685 \\
3. Istishna' & 120 & 25 & 18 & 15 & 15 \\
Ijarah incl. Leasing receivables & 1564 & 1883 & 2791 & 3180 & 3371 \\
\hline Source: (OJK, 2019) & & & & &
\end{tabular}

One of the sharia services that is the focus of research studies is Qardhul Hasan free loan. The Qardhul Hasan's conception is giving loans without expecting anything in return. The loans are used as business capital to develop businesses and provide benefits, or for social purposes only. The loan must be returned with an equivalent return value and is paid back to the debtor according to the agreed contract. The Akad of Qardhul Hasan has principles to help or ease others.

The scholars of fiqh agree that Qardhul Hasan is permissible, on the basis that human nature cannot live independently without the help and 
assistance of others. Humans also basically do not have anything, so he asked for help from others to live their lives. Therefore, lending and borrowing is a part of economic life in the world, and Islam is a religion that is very concerned about all the economic needs of its people (Purwadi, 2014).

The Qardhul Hasan concept is more relevant in the public sector to support the economic empowerment of small communities. The source of Qardhul Hasan's financing in the public sector can come from government or banking budgets through trusted mechanisms (Ismal, 2013). The Qardhul Hasan loan can be used by people who are socially oriented and charitable. Sources of funding come from infaq, shadaqah and donations. Utilization of Qardhul Hasan for charity or social purposes is also very flexible, including to help household interests, such as school fees, helping with the costs of marriage or childbirth (Abidin, Alwi, \& Ariffin, 2011).

Qardhul Hasan loan services are not easily implemented by Islamic financial institutions. Qardhul Hasan's service, without expecting anything in return, can disrupt the performance of profit-oriented financial institutions. In this case, the Qardhul Hasan program is indeed a social mission of Islamic banking. Sharia banking social responsibility also aims to improve the image of banks, increase public loyalty to Islamic banks, and foster community empowerment. Sources of financing Qardhul Hasan Islamic banking can use Corporate Social Responsibility (CSR) (Purwadi, 2014).

The potential for financing the Qardhul Hasan scheme is enormous to empower the community's economy. This is interesting to study by exploring how the experience and implementation of Qardhul Hasan in supporting the financing of microeconomic businesses.

This study aims to describe Qardhul Hasan financing, business performance, compliance with agreements (contracts), and perceptions of Qardhul Hasan loans for the development of micro businesses in the city of Malang.

\section{RESEARCH METHOD}

The study was conducted in the city of Malang, as part of community service activities from the campus. The object of the study was determined purposively, from small or micro businesses that utilize Qardhul Hasan loans. Study in 2016-2018 was conducted to see the micro business performance of a used motorcycle dealer. The business of buying and selling the used motorcycles has a wide range of consumers. The consumers use motorcycles to support transportation, trade businesses, and other economic services.

The results of returning Qardhul Hasan in the used motorcycle dealers are then rolled out to finance other small businesses in 2019. The small businesses receiving loans from Qardhul Hasan, including the vegetable traders, instant noodles, meatballs, ice vendors, and creative economy ventures. This kind of business lives and develops in the community, meets the needs of consumers and impacts the economic independence of society. The number of small traders who received loans initially amounted to 32 units, then reduced to 14 because it did not show positive performance.

The performance of Qardhul Hasan micro loan recipients was measured descriptively. Things that received attention included the ability to repay loans, the compliance with agreements (contracts), as well as the perceptions of Qardhul Hasan loans for business development.

\section{RESULT AND DISCUSSION}

\section{Business Performance of Used Motorcycle Dealers}

The selection of a used motorcycle dealer business was initially for an experiment to see whether it was able to carry out Qardhul Hasan financing. It has also become a kind of learning laboratory for the implementation of Qardhul Hasan financing. The fundamental reason is because Qardhul Hasan is not widely known by the public, especially for micro businesses that are fully commercial like a used motorcycle dealer. It is expected that through the Qardhul Hasan transaction, it can provide alternative win-win solution risk management following sharia regulations.

Even though Islamic banking services are well known, but it relates to the concept of profit sharing, while Qardhul Hasan is fully lending without compensation based on virtue. It is 
according to the basic concept of sharia economics which refers to the verse: You who have believed, if you support Allah, He will support you and plant firmly your feet (QS Muhammad: 7).

Table 2. Business Performance of Used Motorcycle Dealers during 2018 - 2019

\begin{tabular}{|c|c|c|c|c|c|c|}
\hline No & Motorcycle Type & Buy & Sell & $\begin{array}{c}\text { Down } \\
\text { payment }\end{array}$ & Profit & Installment status \\
\hline & & \multicolumn{3}{|c|}{...... thousand rupiahs ...... } & $\%$ & \\
\hline 1 & Honda Beat & 9500 & 11000 & 6000 & 15.8 & Paid off \\
\hline 2 & Honda Revo & 9000 & 10750 & 4000 & 19.4 & Paid off \\
\hline 3 & Honda & 12000 & 14500 & 6850 & 20.8 & Paid off \\
\hline 4 & Honda Vixio & 12000 & 14500 & 4500 & 20.8 & Paid off \\
\hline 5 & Honda Vario & 14250 & 16250 & 8000 & 14.0 & Paid off \\
\hline 6 & Honda & 7000 & 9500 & 2500 & 35.7 & Paid off \\
\hline 7 & Yamaha & 8000 & 10250 & 4550 & 28.1 & Paid off \\
\hline 8 & Honda Beat & 12000 & 14500 & 6000 & 20.8 & Paid off \\
\hline 9 & Spacy & 7500 & 9250 & 2000 & 23.3 & Default \\
\hline 10 & Honda Beat & 13000 & 15300 & 7300 & 17.7 & Paid off \\
\hline 11 & Tecno & 9000 & 12000 & 3000 & 33.3 & Paid off \\
\hline 12 & Honda supra fit & 4000 & 5700 & 2000 & 42.5 & Paid off \\
\hline 13 & Honda Supra fit & 4000 & 5500 & 2000 & 37.5 & Paid off \\
\hline 14 & Honda supra & 4000 & 5100 & 2000 & 27.5 & Cash \\
\hline 15 & Honda revo & 6000 & 8000 & 1000 & 33.3 & Default \\
\hline 16 & Honda supra X & 8000 & 9500 & 4000 & 18.8 & Paid off \\
\hline 17 & Honda beat & 8500 & 10000 & 4000 & 17.6 & Paid off \\
\hline 18 & Honda beat & 16000 & 19000 & 8000 & 18.8 & Paid off \\
\hline 19 & Yamaha Yupiter & 8000 & 10000 & 4000 & 25.0 & Default \\
\hline 20 & Honda CB 150R & 27500 & 31500 & 10000 & 14.5 & Paid off \\
\hline 21 & Honda Vario 125 & 20000 & 22000 & 7000 & 10.0 & Paid off \\
\hline 22 & Yamaha Mio & 5500 & 7000 & 500 & 27.3 & Paid off \\
\hline 23 & Honda supra fit & 6000 & 7500 & 2500 & 25.0 & Default \\
\hline 24 & Honda vario150 & 18000 & 22000 & 11000 & 22.2 & Paid off \\
\hline 25 & Honda vario125 & 12000 & 15000 & 7500 & 25.0 & Paid off \\
\hline 26 & Honda scopy & 21000 & 25000 & 10000 & 19.0 & Paid off \\
\hline 27 & Honda fit & 4500 & 6000 & 2000 & 33.3 & Paid off \\
\hline 28 & Honda vario125 & 19000 & 23250 & 5000 & 22.4 & Default \\
\hline 29 & Yamaha mio & 9000 & 11500 & 3000 & 27.8 & Default \\
\hline 30 & Honda beat & 13000 & 16500 & 6500 & 26.9 & Paid off \\
\hline 31 & Honda revo & 5000 & 9000 & 3000 & 80.0 & Default \\
\hline 32 & Honda revo & 5000 & 7000 & 1500 & 40.0 & Default \\
\hline 33 & Honda beat & 14000 & 15000 & 4000 & 7.1 & Default \\
\hline 34 & Honda vario 150 & 17500 & 24000 & 4000 & 37.1 & Motocycle returned \\
\hline 35 & Honda fit & 9500 & 13000 & 5000 & 36.8 & Paid off \\
\hline 36 & Honda vario 150 & 19000 & 22500 & 4500 & 18.4 & Default \\
\hline 37 & Vega ZR & 7000 & 10750 & 2000 & 53.6 & Default \\
\hline 38 & Honda Vario tecno & 8000 & 13000 & 5000 & 62.5 & Default \\
\hline 39 & Honda Beat & 11000 & 17500 & 7000 & 59.1 & Default \\
\hline 40 & Honda Vario & 6500 & 12000 & 2500 & 84.6 & Default \\
\hline 41 & Honda Vario 110 & 13000 & 14000 & 5000 & 7.7 & Default \\
\hline 42 & Kompresor & 1000 & 1300 & 300 & 30.0 & Default \\
\hline
\end{tabular}

During the 2016-2018 period, the performance of used motorcycle dealers shows the following results. The dealers accepted five choices of transaction models through Qardhul Hasan financing with a relatively high level of risk. However, this high risk could be minimized through agreements that could be offered. Of the 23 customers, only 3 people (13\%s) experienced default installment payments. The average level of business profit was $50 \% \mathrm{~s}$ above the profit of conventional transactions, and by $25 \%$ s above transactions in Islamic financial institutions (Table 2).

\section{Business Performance of Small Traders}

A study of the performance of creative economy ventures was carried out in 2019. They received Qardhul Hasan financing from $2.5 \%$ s of the profits 
of the used motorcycle traders. They consist of business actors such as vegetable traders, instant noodles, meatballs, beverage sellers, and creative economic actors. They join groups to help finance distribution mechanisms and loan repayments. The group is led by a coordinator who assists or facilitates the distribution of Qardhul Hasan or collects savings or loan repayment installments. The position of coordinator is also known as muzakki who allocates the financing from the used motorcycle business.

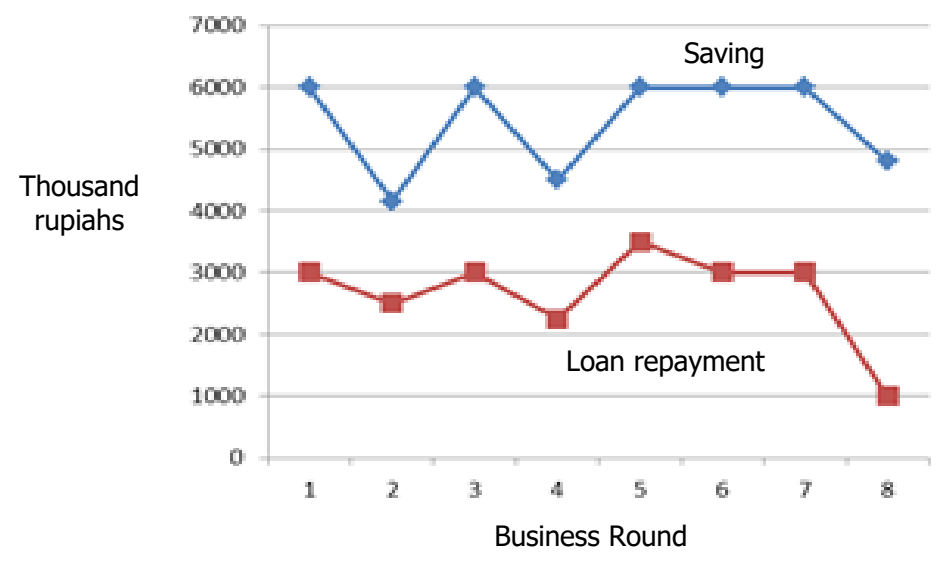

Figure 1. Saving and loan repayment during three months

The results of the study show that Qardhul Hasan financing has a positive impact on the savings of the traders. These savings are merchant savings collected in the coordinator, which are used to pay installments on Qardhul Hasan loan payments. The amount of savings depends on the ability of each target group (Figure 1). These results confirm studies (Utomo et al., 2016) that use financial measures as the success of Qardhul Hasan transactions, including Capital Adequacy Ratio (CAR), Non-Performing Financing (NPF), Net Interest Margin (NIM), Operational Cost to Operational Income (OCOI), Return on Assets (ROA) and Return on Equity (ROE). According to Kadarningsih (2017) the success of Qardhul Hasan financing needs to comply with accounting records as a form of transparency (tabligh) and validity (shidiq) of financial statements, as well as a form of professionalism (fathonah) and accountability (amanah) management.

The results of this study indicate that the transaction in the form of Qardhul Hasan provides a feeling of calm for the target group. They feel comfortable, not burdened with interest in the installments. They are motivated to pay off immediately because they will get loan money again. For this reason, the installment payment mechanism is carried out alternately from all members of the target group. This is done to (i) minimize operational costs that must be received jointly and (ii) support the smooth installment payment so that there is no traffic jam.

The financing of the Qardhul Hasan transaction is unique or superior, i.e. (i) respecting the agreement; (ii) courage to oppose rent seeker behavior; (iii) the form of agreement without guarantee; (iv) creating friendship in groups; (v) motivating to save as a 'guarantee' on installments; (vi) the installment mechanism is carried out by members; (vii) each member must take turns coordinating and sending installments to the bank lending institution; (ix) there are no fees for lending or collecting installments.

The study also found problems in implementing Qardhul Hasan by the traders. The main problem was the issue of defaults on repaying loans. Loss, or incomplete installments in a group, make the group not being able to get a loan in the next period. However, installment payment bottlenecks are generally within reasonable limits, which is two to five days from the agreed deadline. In general, 
the risk of a successful Qardhul Hasan transaction is $90 \% \mathrm{~s}$, while the rest, $10 \% \mathrm{~s}$, is categorized as default. This was then resolved by making friendship to draw up mutual agreement. The solution to overcome the loss in installment payments is pursued through the simultaneous billing of traders according to the agreement.

In general, the positive side of the Qardhul Hasan transaction is that the loan installments are relatively smooth. Economic agents can carry out payment obligations with happiness. The happiness that emerges is the same as the meaning of blessing. Blessing is believed from God as a source of virtue. Lending wealth or helping someone without usury is believed to be a charity and get a return or reward. QS.Taubah: 105, states that Allah says, and you will be returned to the One who know the Unseen, and He will inform you of what you used to do. In addition, QS.Al-Baqarah: 274; also stated that those who spend their wealth [in Allah's way] by night and by day, secretly and publicly - they will have their reward with their Lord, and no fear will be there concerning them, nor will they grieve.

The motivation to avoid usury is the implementation of the life of a Muslim. Usury is synonymous with taking or consuming other people's rights. It is described as people who could not stand up or as standing people who were possessed by devils with madness. The person who takes usury is not at peace in his soul, so that the person is the inhabitants of hell and they are eternal in it.

On the contrary, a Muslim should do shadaqah, so that the wealth that has been given is blessed. Qardhul Hasan transaction becomes relevant because it can develop the benefits of alms while avoiding usury.

\section{Implications for Developing Qardhul Hasan}

The implications of developing the Qardhul Hasan program on a larger scale need to be considered. Qardhul Hasan's potential funding sources are widely open from various parties. First, it is from Muslims. The huge economic potential of Muslims in Indonesia provides alternative sources of funding, such as zakat, shadaqah, infaq or other sources that meet the sharia provisions. Second, it is from the government. Lots of public sectors programs are the responsibility of the government, especially for the development of small businesses and poverty alleviation. Revolving funds or small business credit programs can implement the Qardhul Hasan mechanism. Third, it is from CSR. Regulations and provisions regarding CSR have been implemented to develop productive sectors, social activities, and community development. This can be done by corporate businesses or can be sourced from Islamic banking CSR in accordance with their respective vision and mission.

Some thoughts on developing Qardhul Hasan are presented below.

1. Qardhul Hasan is a loan, not a grant or assistance.

It is often found differences in understanding or perception of the concept of Qardhul Hasan. Qardhul Hasan is a form of virtue to lend to other parties. Borrowers are required to return according to the agreement. This understanding needs to be widely disseminated, especially to the government or CSR implementers. These two parties are accustomed to providing assistance, grants or the like, in order to implement the obligations of the vision-mission or program. The important implication is the need to strengthen the institutional implementation of Qardhul Hasan, the formation and distribution of roles to oversee the loan repayments. It must be recognized that the government or corporation does not have the competence of the task of overseeing loan repayments.

\section{Strengthening groups}

The target of the Qardhul Hasan program is to increase productivity and empower small and micro businesses. Because there are so many of them, management in groups is effectively implemented in various needs (Hassan, 2014). Islamic microfinance based groups have the potential for social capital. This can strengthen the intention and behavior to increase the commitment to repay their loan. Group strengthening can be a program recommendation, and consider groups as partners in realizing poverty alleviation programs (Sanrego \& Antonio, 2015). Therefore, efforts to strengthen groups become important through several efforts. First, it is from mapping and group categories. Efforts can be made on the grouping based on the 
types of businesses (for example business groups of meatballs, cilok or the like), the place of business (for instance traders in traditional markets), the social closeness (such as groups of housewives), or other similar characteristics. Second, within the group, various activities are carried out, such as business development, management assistance, or lending and collection of savings or payment of Qardhul Hasan installments. In groups, training is also conducted in terms of group management, leadership, and increasing the role of members.

\section{Socialization of Qardhul Hasan}

The Qardhul Hasan program is often the umpteenth priority in CSR programs, Islamic banking service products, or government programs. This half-hearted intention is because the management of Qardhul Hasan is directed more towards social missions. This is like being a hidden intention. This perspective must be changed. The socialization and promotion of Qardhul Hasan need to be carried out to all segments of community; therefore, it elevates the position of Qardhul Hasan as a priority. The institution of Qardhul Hasan must also be known and promoted so that the mechanism of responsibility for managing Qardhul Hasan is known to all parties. This is also to fulfill the mandate of the owner of the funding source so that his benevolent intentions become a real charity. The faster loans are expended, the faster economic development is realized.

\section{Management of Qardhul Hasan}

The management of Qardhul Hasan at the micro level relating to the supervision of loan repayments is the most crucial. This task certainly requires high operational costs, and cannot be taken from Qardhul Hasan. These costs must be available specifically as CSR social missions, or particular government assistance, or particular social allocations. Management must be comprehensive without disrupting the contract and intention of Qardhul Hasan. At the macro level, the management of Qardhul Hasan can involve the central bank, by issuing special Qardhul Hasan certificates with certain time frames. Most importantly, the management of Qardhul Hasan should be professional because the central bank bears all losses coming from such funds. In this case, to minimize the chance of having losses, the central bank might ideally finance government projects which should be maintained professionally by both the central bank and the government and is provided for the benefits of the public (Ismal, 2013).

\section{CONCLUSION AND SUGGESTION}

The implementation of Qardhul Hasan was positively welcomed by traders or micro-economic entrepreneurs. They joined a group to help finance mechanisms, and repay loans of Qardhul Hasan. The group is led by a coordinator who helps or facilitates the distribution of the loans, collects savings or loan repayment installments.

Economic actors managed to collect savings in an effort to repay loan installments. The Qardhul Hasan transaction provides a feeling of calm and happiness for economic actors because loan repayments do not have cost implications and flexible repayment times.

This study has implications for development including understanding the concept of Qardhul Hasan as loan financing, strengthening groups for small businesses, management mechanisms of Qardhul Hasan at the micro to the national level, and the socialization of Qardhul Hasan programs.

\section{REFERENCES}

Abduh, M., \& Azmi Omar, M. (2012). Islamic banking and economic growth: the Indonesian experience. International Journal of Islamic and Middle Eastern Finance and Management, 5(1), 35-47.

https://doi.org/10.1108/17538391211216811

Abidin, A. Z., Alwi, N. M., \& Ariffin, N. M. (2011). A Case Study on the Implementation of Qardhul Hasan Concept as a Financing Product in Islamic Banks in Malaysia. International Journal of Economics, Management and Accounting, 19(3), 81-99. Retrieved from https://journals.iium.edu.my/enmjournal/index. php/enmi/article/view/201

Cahyono, Y., \& Kurniawan, E. (2017). Perkembangan Perekonomian Syari'ah Pada Masyarakat Ponorogo (Analisis Faktor Internal dan Eksternal). Muaddib: Studi Kependidikan Dan Keislaman, 6(2), 147-161. https://doi.org/10.24269/muaddib.v6i2.281 
Hassan, A. (2014). The challenge in poverty alleviation: Role of Islamic microfinance and social capital. Humanomics, 30(1), 76-90. https://doi.org/10.1108/H-10-2013-0068

Ismal, R. (2011). Islamic Banking in Indonesia: Lesson to be Learned. UNCTAD: Multi-Year Expert Meeting on Services, Development and Trade: The Regulatory and Institutional Dimension. Geneva, 6-8 April 2011. Retrieved from

http://www.financialislam.com/uploads/3/8/5/3/ 3853592/cimem3 3rd country paper indonesia 1.pdf

Ismal, R. (2013). The Islamic gracious monetary instruments: a theoretical approach. Journal of Economic and Administrative Sciences, 29(1), 63-80.

https://doi.org/10.1108/10264111311319231

Kadarningsih, A. (2017). Penyajian Akuntansi Qardhul Hasan Dalam Laporan Keuangan Perbankan Syariah. JESI (Jurnal Ekonomi Syariah Indonesia), 7(1), 32. https://doi.org/10.21927/jesi.2017.7(1).32-41

OJK. (2019). Sharia Banking Statistics. (Indonesia Financial Services Authority, Ed.). Jakarta:
Otoritas Jasa Keuangan, Kemenkeu RI. Retrieved from https://www.ojk.go.id/id/kanal/syariah/datadan-statistik/statistik-perbankansyariah/Documents/Pages/Statistik-PerbankanSyariah---Januari-2019/SPS Januari 2019.pdf

Purwadi, M. I. (2014). Al-Qardh dan Al-Qardhul Hasan sebagai Wujud Pelaksanaan Tanggung Jawab Sosial Perbankan Syariah. Jurnal Hukum IUS QUIA IUSTUM NO, 21(1), 24-42. https://doi.org/10.20885/iustum.vol21.iss1.art2

Sanrego, Y., \& Antonio, M. (2015). The Effect of Social Capital on Loan Repayment Behavior of The Poor (A Study on Group Lending Model (GLM) Application In Islamic Microfinance Institution). Jurnal Ekonomi \& Bisnis Indonesia (Fakultas Ekonomi Dan Bisnis Universitas Gadjah Mada), 28(2), 188-210. https://doi.org/10.22146/jieb.6222

Utomo, A. S., Maharani, N. K., \& Octavio, D. Q. (2016). Financial Determinants of Qardhul Hasan Financing Growth: Evidence from Islamic Banks in Indonesia. Global Review of Islamic Economics and Business, 3(1), 38-45. https://doi.org/10.14421/grieb.2015.031-03 